BONAFIDE: Jurnal Teologi dan Pendidikan Kristen

www.jurnal.sttissiau.ac.id/Volume 2/Nomor 2/Desember 2021/hal.266-281

\title{
PERANAN KELOMPOK SEL TERHADAP PERTUMBUHAN GEREJA HOME COMMUNITY CHURCH (HCC) DI JEMAAT PALU
}

\author{
Nustince Maki, Purnama Pasande, Oskar Sopang, Niel Parinsi \\ Sekolah Tinggi Teologi Star's Lub Luwuk Banggai \\ nustincemaki@gmail.com
}

Diterima tanggal: 21-12-2021

Dipublikasikan tanggal: 23-12-2021

\begin{abstract}
The church wants the congregation's spirituality to experience growth. The number of membership is decreasing. At Home Community Church (HCC) Palu, a small group performs the process of renewal, leading to the likeness of Christ and training men to become fishers of men. Through small groups (Komsel), it is hoped that the congregation's growth will increasingly have a positive effect on the communion and church growth. The respondents were 144 Komsel members from a total population of 212 members. The method used in this study is a quantitative method with a Likert scale questionnaire as a research instrument. In this study, the role of Komsel significantly affects the number of HCC church congregations and provides benefits in service, evangelizing, teaching, and communion programs.
\end{abstract}

Keywords: Small Group, Home Community Church (HCC), Church Growth

\begin{abstract}
Abstrak. Gereja menginginkan kerohanian jemaat mengalami pertumbuhan namun kenyataanya jumlah keanggotaan semakin berkurang. Di Home Community Church (HCC) Palu, kelompok kecil melakukan proses pemuridan dengan menuntun pada keserupaan akan Kristus dan melatih orang untuk menjadi penjala manusia. Melalui kelompok sel (Komsel) diharapkan pertumbuhan jemaat semakin berdampak positif terhadap persekutuan dan pertumbuhan gereja. Subyek yang diteliti berjumlah 144 anggota Komsel dari jumlah populasi 212 anggota. Metode yang di gunakan dalam penelitian ini adalah metode kuantitatif dengan kuesioner berskala likert sebagai instrument penelitian. Dalam penelitian ini peranan Kelompok Sel sangatlah berpengaruh pada jumlah jemaat HCC Palu dan memberikan manfaat dalam program pelayanan gereja baik itu dalam pelayanan, penginjilan, pengajaran maupun persekutuan.
\end{abstract}

Kata Kunci: Komsel, Home Community Church (HCC), Pertumbuhan Gereja

\section{PENDAHULUAN}

Gereja adalah kumpulan orang percaya kepada Tuhan dan yang mengarahkan seluruh kehidupannya sesuai dengan apa yang dikehendaki Tuhan Yesus (Susanto 
BONAFIDE: Jurnal Teologi dan Pendidikan Kristen

www.jurnal.sttissiau.ac.id/Volume 2/Nomor 2/Desember 2021/hal.266-281

2019). Setiap gereja pasti menginginkan kerohanian jemaat bertumbuh. Sebagai sebuah organisasi Secara organisasi yang sehat pun di dalamnya pasti mengalami pertumbuhan, perkembangan dan pembangunan (Widjaja 2019). Namun pada kenyataannya terdapat gereja yang saat ini mengalami kemunduran, salah satunya dapat dilihat dari jumlah anggotannya yang semakin berkurang.

Laia (2019) berpendapat bahwa Kristus menginginkan gereja-Nya memiliki kepercayaan/iman yang teguh kepada-Nya. Gereja yang memiliki pengetahuan yang benar tentang Dia, tetap berpegang pada kebenaran Alkitab, dan bertumbuh dalam kasih Allah dan sesama umat manusia. Gereja yang semakin meningkatkan hubungan pribadi dengan Allah dan berani dalam memikul tanggung jawab dan pelayanan gereja (Efesus $4: 13-15)$.

Salah satu indikator pertumbuhan gereja adalah terjadinya pertambahan anggota jemaat secara konsisten dari waktu ke waktu. Laia yang menyatakan bahwa pertumbuhan gereja dapat dilihat dari bertambahnya jumlah anggota jemaatnya dan gereja yang bertambah anggotanya juga termasuk gereja yang sehat. Pertambahan anggota jemaat dapat terjadi karena masuknya anggota jemaat baru luar, termasuk karena adanya kegiatan pekabaran Injil atau misi (Laia 2019).

Namun di sejumlah gereja terdapat kelompok yang berpengaruh terhadap pertambahan anggota jemaat, yaitu kelompok sel atau yang biasa disingkat dengan Komsel. Komsel adalah kelompok kecil yang anggotanya memberi diri mereka untuk belajar bersama- sama tentang kebenaran firman Tuhan, saling memperhatikan 
BONAFIDE: Jurnal Teologi dan Pendidikan Kristen

www.jurnal.sttissiau.ac.id/Volume 2/Nomor 2/Desember 2021/hal.266-281

satu dengan yang lainnya, membimbing, menolong, mengasihi bahkan bertumbuh dalam Kristus secara pribadi dan keluarga (Sutoyo 2012). Dalam Komsel, seseorang dapat belajar bagaimana menghargai orang, menjadi rendah hati, menyesuaikan diri, mengembangkan pemikiran, berbicara dan bertindak. Komsel dapat dijadikan sebagai sarana untuk lebih mengenal Tuhan, bertumbuh dalam persekutuan dengan sesama anggota dan saling menasehati, mendorong agar dapat lebih bertumbuh dalam iman.

Komsel juga dapat berupa sebuah kelompok yang sangat kecil dengan tujuan untuk terus-menerus meningkatkan rasa tanggungjawab dan terus meningkatkan keakraban antar anggota. Komsel juga adalah kelompok kecil yang memungkinkan adanya suatu komitmen keterlibatan untuk bersama-sama bertumbuh (Widjaja 2019).

Strategi pelayanan dengan pendekatan kelompok kecil ada sejak masa pelayanan Yesus di dunia dan pada masa pekabaran Injil mula-mula oleh para rasul. Kelompok kecil atau persekutuan yang ada di rumah-rumah dalam konteks pelayanan para rasul merupakan salah satu dasar untuk melaksanakan serta menjalankan kegiatan misi yang Tuhan Yesus berikan. Pada sistem Komsel yang Yesus lakukan, Ia memiliki tujuan yakni Komsel dengan memuridkan kedua belas orang yang telah dipilih untuk meneruskan misi kerajaan Allah (Berutu dan Siahaan 2020).

Latif menekankan pentingnya diadakan Komsel di lingkungan jemaat, sebab Komsel dapat dijadikan sebagai sarana dalam gereja untuk menemukan masalah yang ada pada sekelompok orang-orang yang kaku dalam lingkungan kelompok mereka sendiri. Ia juga menekankan bahwa pengelompokkan dalam Komsel dapat menjadi 
BONAFIDE: Jurnal Teologi dan Pendidikan Kristen

www.jurnal.sttissiau.ac.id/Volume 2/Nomor 2/Desember 2021/hal.266-281

penyambung dalam pelayanan gereja dengan menjalankan prinsip pemuridan (Latif 2018).

Gereja Home Comunity Church (HCC) Jemaat Palu juga memiliki Komsel yang aktif melakukan proses pemuridan. Pemuridan dalam gereja HCC bukan sekedar curahan hati atau mencari tempat berbagi perasaan emosional seseorang, melainkan gereja ini melakukan proses pemuridan dengan tujuan menuntun pada keserupaan akan Kristus dan melatih orang untuk menjadi penjala manusia.

Sejak kehadirannya, Komsel di gereja HCC di Jemaat Palu terus mengalami pertumbuhan signifikan sebagaimana tergambar pada Tabel 1. Hingga penelitian ini dilakukan, gereja HCC Jemaat Palu telah memiliki 20 Komsel yang terdiri atas: kelompok Family 7 kelompok, kelompok Pro-M 6 Kelompok, kelompok pemuda/mahasiswa 4 KOMSEL, kelompok remaja dalam tingkat pendidikan (SMP/ Junior) 1 kelompok dan Tingkat (SMA/Senior) 2 kelompok.

Kegiatan dalam KOMSEL yakni ibadah, sharing, bermain game, makanmakan bersama dan saling mendoakan. Ibadah minggu dilakukan sebanyak tiga kali dan ibadah Connect Group (CG) On-line dilakukan setiap hari. Setiap khotbah yang dibawakan di hari Minggu dalam ibadah Connect Grup akan tetap dibahas kembali dengan tujuan agar jemaat benar-benar mengerti kebenaran firman Tuhan. 
BONAFIDE: Jurnal Teologi dan Pendidikan Kristen

www.jurnal.sttissiau.ac.id/Volume 2/Nomor 2/Desember 2021/hal.266-281

Tabel 1. Peningkatan Jumlah Komsel Tahun 2018 - 2021

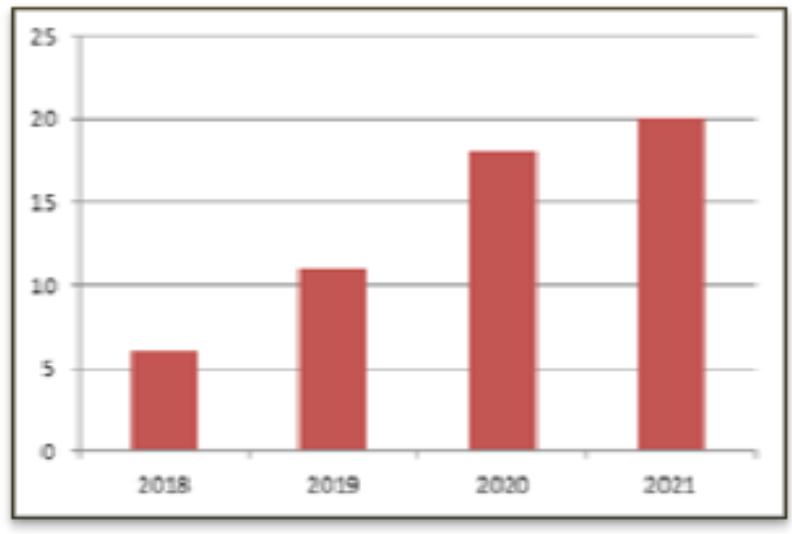

Berdasarkan bentuk kegiatan pelayanan yang dilakukan bisa dikatakan Komsel merupakan sebuah metode pelayanan KOMSEL yang memberi ruang bagi anggotanya ataupun jemaatnya bertumbuh. Pertanyaannya, apakah Komsel ini berpengaruh dalam pertumbuhan gereja HCC Jemaat Palu? Hal inilah yang akan diteliti dengan tujuan mengetahui pengaruh Kelompok Sel terhadap pertumbuhan gereja HCC di Jemaat Palu melalui peningkatan jumlah anggota KOMSEL.

Berdasarkan Kamus Besar Bahasa Indonesia, kata "pengaruh” berarti daya yang ada atau timbul dari sesuatu (orang, benda) yang ikut membentuk watak, kepercayaan, atau perbuatan seseorang (KKBI n.d.). Berdasarkan pengertian ini, maka dalam penelitian ini daya yang ikut membentuk watak tersebut adalah seperti yang dikemukakan Fitriani yaitu lebih condong kepada sesuatu yang membawa perubahan menuju arah yang lebih positif (Fitriani 2014).

Dengan demikian penelitian terhadap pengaruh komsel terhadap pertumbuhan gereja diukur secara kualitatif yaitu bagaimana Komsel memberi daya positif bagi 
BONAFIDE: Jurnal Teologi dan Pendidikan Kristen

www.jurnal.sttissiau.ac.id/Volume 2/Nomor 2/Desember 2021/hal.266-281

anggotanya untuk terlibat dalam pelayanan di gereja yang mencerminkan terjadinya pertumbuhan gereja.

\section{METODE PENELITIAN}

Penelitian ini dilakukan di gereja HCC Palu yang letaknya di Jln. Towua, Kecamatan Palu Selatan, Kota Palu Sulawesi Tengah. Metode penelitian yang digunakan adalah kuantitatif dengan teknik pengumpulan data menggunakan kuesioner dengan skala Likert. Indikator yang digunakan untuk mengukur peranan Komsel dalam pertumbuhan Gereja HCC Palu adalah: 1) penginjilan, 2) persekutuan, 3) pengajaran, 4) pelayanan. Analisis data menggunakan program SPSS for windows 21.

Responden yang dilibatkan adalah Gembala Gereja dan anggota KOMSEL HCC Palu. Teknik sampling yang digunakan yaitu teknik Simple Random Sampling. Jumlah populasi dari penelitian ini 212 dan sampelnya berjumlah 144. Jumlah sampel diambil $70 \%$ dari jumlah populasi penelitian. Hal ini dilakukan sesuai pendapat Sugiyono bahwa semakin tinggi sampel yang digunakan semakin akurat data yang akan di dapatkan (Sugiyono, 2015).

Hipotesis yang diajukan adalah:

$\mathrm{H}_{0} \quad$ : Kelompok Sel Jemaat HCC Palu tidak berpengaruh terhadap pertumbuhan gereja

$\mathrm{H}_{1} \quad$ : Kelompok Sel Jemaat HCC Palu berpengaruh terhadap pertumbuhan gereja 
BONAFIDE: Jurnal Teologi dan Pendidikan Kristen

www.jurnal.sttissiau.ac.id/Volume 2/Nomor 2/Desember 2021/hal.266-281

\section{HASIL PENELITIAN}

Berdasarkan hasil penelitian, hipotesis alternatif $\left(\mathrm{H}_{1}\right)$ yang menyatakan bahwa kelompok Sel Jemaat HCC Palu berpengaruh terhadap pertumbuhan gereja diterima. Pengaruh Komsel dilihat pada aspek penginjilan, persekutuan, pengajaran, dan pelayanan.

Tabel 2. Jawaban responden atas pernyataan:

"Saya selalu menginjili keluarga yang ada dirumah sejak masuk Kelompok Sel"

\begin{tabular}{|c|c|c|}
\hline Alternatif Jawaban & Frekuensi & \% \\
\hline Sangat setuju & 15 & 10,4 \\
\hline Setuju & 62 & 43,1 \\
\hline Netral & 52 & 36,1 \\
\hline Tidak Setuju & 15 & 10,4 \\
\hline Sangat Tidak Setuju & - & - \\
\hline Jumlah & 144 & 100 \\
\hline
\end{tabular}

Berdasarkan Tabel 2 di atas dapat dilihat bahwa jumlah responden yang menjawab sangat setuju berjumlah $10,4 \%$, responden yang menjawab setuju berjumlah $43,1 \%$, responden yang menjawab netral berjumlah $36,1 \%$, responden yang menjawab tidak setuju berjumlah $10,4 \%$, dan responden yang menjawab sangat tidak setuju berjumlah 0\%. Sehingga dapat disimpulkan bahwa sebagian besar responden selalu menginjili keluarga yang ada di rumah sejak masuk Kelompok Sel.

Tabel 3. Jawaban responden atas pernyataan:

Saya ikut persekutuan doa sejak dalam KOMSEL"

\begin{tabular}{|c|c|c|}
\hline Alternatif Jawaban & Frekuensi & \% \\
\hline Sangat setuju & 15 & 10,4 \\
\hline Setuju & 69 & 47,9 \\
\hline Netral & 45 & 31,3 \\
\hline
\end{tabular}


BONAFIDE: Jurnal Teologi dan Pendidikan Kristen

www.jurnal.sttissiau.ac.id/Volume 2/Nomor 2/Desember 2021/hal.266-281

\begin{tabular}{|c|c|c|}
\hline Tidak Setuju & 15 & 10,4 \\
\hline Sangat Tidak Setuju & - & - \\
\hline Jumlah & 144 & 100 \\
\hline
\end{tabular}

Berdasarkan Tabel 3, dapat dilihat bahwa jumlah responden yang menjawab sangat setuju berjumlah 10,4\%, responden yang menjawab setuju berjumlah $47,9 \%$, responden yang menjawab netral berjumlah $31,3 \%$, responden yang menjawab tidak setuju berjumlah $10,4 \%$, dan responden yang menjawab sangat tidak setuju berjumlah 0\%. Sehingga dapat disimpulkan bahwa sebagian besar responden ikut persekutuan doa sejak dalam KOMSEL.

Tabel 4. Jawaban responden atas pernyataan:

"Saya mengajarkan orang lain untuk hidup terbuka dihadapan Tuhan sejak ikut KOMSEL"

\begin{tabular}{|c|c|c|}
\hline Alternatif Jawaban & Frekuensi & \% \\
\hline Sangat setuju & 18 & 12,5 \\
\hline Setuju & 84 & 58,3 \\
\hline Netral & 37 & 25,7 \\
\hline Tidak Setuju & 5 & 3,5 \\
\hline Sangat Tidak Setuju & - & - \\
\hline Jumlah & 144 & 100 \\
\hline
\end{tabular}

Berdasarkan tabel 4, dapat dilihat bahwa jumlah responden yang menjawab sangat setuju berjumlah $12,5 \%$, responden yang menjawab setuju berjumlah $58,3 \%$, responden yang menjawab netral berjumlah $25,7 \%$, responden yang menjawab tidak setuju berjumlah 3,5\%, dan responden yang menjawab sangat tidak setuju berjumlah 
BONAFIDE: Jurnal Teologi dan Pendidikan Kristen

www.jurnal.sttissiau.ac.id/Volume 2/Nomor 2/Desember 2021/hal.266-281

$0 \%$. Sehingga dapat disimpulkan bahwa sebagian besar responden mengajarkan orang lain untuk hidup terbuka dihadapan Tuhan sejak ikut KOMSEL.

Tabel 5. Jawaban responden atas pernyataan:

"Saya selalu melayani orang yang merasa dirinya tidak lagi berguna sejak ikut KOMSEL"

\begin{tabular}{|c|c|c|}
\hline Alternatif Jawaban & Frekuensi & \% \\
\hline Sangat setuju & 28 & 19,4 \\
\hline Setuju & 64 & 44,4 \\
\hline Netral & 40 & 27,8 \\
\hline Tidak Setuju & 12 & 8,3 \\
\hline Sangat Tidak Setuju & - & - \\
\hline Jumlah & 144 & 100 \\
\hline
\end{tabular}

Berdasarkan tabel 5, dapat dilihat bahwa jumlah responden yang menjawab sangat setuju berjumlah $19,4 \%$, responden yang menjawab setuju berjumlah $44,4 \%$, responden yang menjawab netral berjumlah $27,8 \%$, responden yang menjawab tidak setuju berjumlah $8,3 \%$, dan responden yang menjawab sangat tidak setuju berjumlah $0 \%$. Sehingga dapat disimpulkan bahwa sebagian besar responden selalu melayani orang yang merasa dirinya tidak lagi berguna sejak ikut KOMSEL.

\section{PEMBAHASAN}

\section{Daya Tarik Komsel Bagi Anggota}

Pertambahan jumlah anggota Komsel di gereja HCC Palu menunjukkan bahwa Komsel memiliki daya tarik tersendiri bagi jemaat yang bergabung di dalamnya. Hal tersebut mendorong setiap anggota berpartisipasi aktif yang tercermin 
BONAFIDE: Jurnal Teologi dan Pendidikan Kristen

www.jurnal.sttissiau.ac.id/Volume 2/Nomor 2/Desember 2021/hal.266-281

dari data bahwa sebagian besar anggota menyatakan: (1) selalu menginjili keluarga yang ada dirumah sejak masuk Komsel; (2) ikut persekutuan doa sejak dalam Komsel; (3) mengajarkan orang lain untuk hidup terbuka dihadapan Tuhan sejak ikut Komsel, dan (4) selalu melayani orang yang merasa dirinya tidak lagi berguna sejak ikut Komsel.

Sedikitnya ada tiga hal yang menarik. Pertama, kelompok sel sebagai kelompok kecil memungkinkan anggota untuk saling memperhatikan dan saling mempedulikan satu sama lain. Gidion mengatakan bahwa pertumbuhan gereja dapat terjadi jika setiap anggota melayani anggota-anggota yang lain dan menerima pelayanan dari anggota yang lain (Gidion 2017). Ini mewujudkan konsep persektuan tempat di mana orang saling menasehati agar iman mereka tetap tekun dalam Tuhan (Wijaya 2015; Padang dan Busthan 2019).

Kedua, kelompok sel memungkinkan setiap anggota untuk mengembangkan talenta masing-masing. Seperti dikatakan Berutu dan Siahaan, tujuan dari Kelompok Sel yaitu untuk membawa dan membina jiwa-jiwa baru serta melatih semua anggota sel menjadi pemimpin yang melayani (Berutu dan Siahaan 2020).

Ketiga, kelompok sel memungkinkan setiap anggota untuk berpartisipasi aktif dalam pelayanan. Setiap anggota berproses dalam pendewasaan untuk melibatkan diri dalam pelayanan (Padang dan Busthan 2019) seperti yang Tuhan Yesus perintahkan di dalam Matius 28:19-20, yaitu perintah memberitakan kabar sukacita kepada semua orang dan menjadikan mereka semua menjadi pengikut Kristus (Hosea 2019). 
BONAFIDE: Jurnal Teologi dan Pendidikan Kristen

www.jurnal.sttissiau.ac.id/Volume 2/Nomor 2/Desember 2021/hal.266-281

Melalui Komsel seseorang dapat tampil sebagai sesuatu yang berbeda, menyerupai Kristus yang telah hidup (Siregar 2021).

\section{Pengaruh Komsel Melalui Penginjilan}

Laia menyatakan bahwa pertumbuhan gereja sangat berkaitan erat dengan pemberitaan injil. Gereja dipanggil untuk memberitakan injil dan pemberitaan injil memiliki tujuan untuk menghasilkan jemaat. Gereja harus memberitakan injil karena injil merupakan amanat agung yang di berikan Tuhan kepada setiap murid-muridnya (Laia 2019). Margareta bahkan mengatakan bahwa penginjilan adalah pusat pertumbuhan gereja. Gereja tidak akan benar-benar bertumbuh kecuali membuktikan perhatian bersama untuk meneruskan pesannya kepada dunia (Margareta 2020).

Dari hasil penelitian, sebagian besar responden menyatakan selalu menginjili keluarga yang ada di rumah sejak masuk Komsel. Elis mengatakan bahwa penginjilan pada dasarnya merupakan upaya pewartaan Yesus Kristus sebagai Juruselamat sehingga setiap orang yang diinjili akan menerima-Nya, taat dan melayani-Nya, serta hidup dalam persekutuan gereja-Nya (dalam Sophia, Widjaja, dan Papay 2019). Meskipun penginjilan yang dilakukan sebatas kepada keluarga masing-masing, namun hal tersebut bisa sangat berpengaruh kepada peningkatan partisipasi aktif anggota jemaat ke dalam kegiatan pelayanan gereja. Sebab umumnya di gereja-gereja tingkat partisipasi anggota jemaat dalam pelayanan gereja tidak sebesar data statistik yang ada di gereja. 
BONAFIDE: Jurnal Teologi dan Pendidikan Kristen

www.jurnal.sttissiau.ac.id/Volume 2/Nomor 2/Desember 2021/hal.266-281

\section{Pengaruh Komsel Melalui Persekutuan}

Sebagian besar responden menyatakan ikut persekutuan doa sejak dalam Komsel. Doa sangat penting dalam persekutuan jemaat. Orang yang rajin berdoa biasanya adalah orang-orang aktif dalam pelayanan Tuhan. Sebab seperti dikatakan Mudak, dengan berdoa, orang percaya membangun komunikasi dengan Tuhan, sehingga akan semakin mengenal Tuhan, semakin bersandar pada-Nya dan semakin bergantung pada Tuhan (Mudak 2017).

Keaktifan anggota Komsel dalam persekutuan akan meningkatkan aktifitas pelayanan gereja sebagai cerminan gereja yang mengalami pertumbuhan. Dalam gereja HCC persekutuan bukan hanya sebagai tempat di mana orang berkumpul, tetapi dalam persekutuan tempat di mana orang saling memberi penguatan, mendoakan dan saling menopang orang-orang yang lemah imannya.

\section{Pengaruh Komsel Melalui Pengajaran}

Gereja merupakan tempat orang Kristen bersekutu serta tempat di mana orang Kristen mendapat pengajaran tentang iman Kristiani (Ritonga 2020). Tujuan pengajaran dalam gereja bukan sebatas pada pengenalan terhadap Tuhan, namun terutama adalah untuk menghasilkan perubahan dalam kehidupan seseorang setelah mendapatkan pengenalan tentang Tuhan (Soeherman 2003).

Untuk itu setiap pengajar di gereja perlu mendorong orang-orang yang diajarnya hidup terbuka di hadapan Tuhan. Sebagian besar responden penelitian ini menyatakan telah berpartisipasi mengajarkan orang lain untuk hidup terbuka di 
BONAFIDE: Jurnal Teologi dan Pendidikan Kristen

www.jurnal.sttissiau.ac.id/Volume 2/Nomor 2/Desember 2021/hal.266-281

hadapan Tuhan sejak ikut Komsel. Mereka ini, seperti dikatakan Sutoyo, adalah orang yang mau bertumbuh di dalam Kristus, hidup berbagi beban dan pengalaman yang di hadapi terhadap orang lain dan hidup terbuka di hadapan Tuhan (Sutoyo 2012). Semakin banyak anggota jemaat yang terlibat dalam pengajaran, tentu akan mendorong pertumbuhan jemaat, yaitu perubahan hidup ke arah yang positif sebagai dampak dari pengenalan kepada Tuhan.

\section{Pengaruh Komsel Melalui Pelayanan}

Melayani juga adalah kunci pertumbuhan gereja. Menurut Gidion pertumbuhan gereja dapat terjadi jika setiap anggota melayani anggota-anggota yang lain dan menerima pelayanan dari anggota yang lain (Gidion 2017).

Selain itu, di dalam gereja tidak sedikit anggota jemaat yang merasa "terasing" dalam persekutuan karena suatu sebab. Mereka ini seperti kaum miskin, kaum lajang, kaum LGBT, pecandu narkoba, dan lain-lain. Tanpa sadar, tidak jarang jemaat seperti ini "diasingkan" oleh jemaat lainnya. Mereka pun bisa saja melihat diri secara negatif juga. Akiba terburuk mereka menarik dari persekutuan-persekutuan jemaat yang berdampak pada melemahnya pertumbuhan gereja.

Sebagian besar responden dalam penelitian ini menyatakan selalu melayani orang yang merasa dirinya tidak lagi berguna sejak ikut Komsel. Artinya mereka sangat mungkin memberi perhatian kepada orang-orang yang "tersingkir" ini. Sebab itu keterlibatan mereka ke dalam pelayanan akan berkontribusi pada pertumbuhan gereja. 
BONAFIDE: Jurnal Teologi dan Pendidikan Kristen

www.jurnal.sttissiau.ac.id/Volume 2/Nomor 2/Desember 2021/hal.266-281

\section{KESIMPULAN}

Kegelisahan gereja terhadap pertumbuhan kerohanian jemaat menjadi perhatian saat ini di mana jumlah keanggotaan jemaat mengalami penurunan. Di gereja HCC Palu, sejumlah kelompok kecil (Komsel) memiliki peranan untuk menjangkau setiap anggota jemaat dalam misi pemuridan. Adanya Komsel, tidak hanya berdampak pada jumlah keanggotaan yang meningkat tetapi juga pada misi penginjilan dan persekutuan dalam gereja.

Berdasarkan hasil dari penelitian penulis, dapat disimpulkan bahwa dalam hal ini, Komsel bukan hanya jumlah anggota Komsel-nya yang bertambah tetapi juga dengan pelayanan Komsel ini dapat membentuk pribadi seseorang untuk hidup terbuka dihadapan Tuhan, saling memberi, saling mendoakan satu dengan yang lainnya bahkan menjangkau jiwa. Dengan demikian, pertumbuhan gereja dalam kerohanian jemaatnya semakin berkembang menurut prinsip pemuridan yang diajarkan Kristus.

Untuk menjadikan Komsel yang sehat dan bermultiplikasi maka diperlukan kerjasama antara gembala dengan para pemimpin Komsel serta jemaat perlu untuk terus dibimbing agar jemaat hidup didalam Tuhan dan lebih mengenal Dia melalui firman-Nya.

\section{DAFTAR PUSTAKA}

Berutu, Irwanto, dan Harls R. Evan Siahaan. 2020. "Menerapkan Kelompok Sel Virtual di Masa Pandemi Covid-19." SOTIRIA (Jurnal Theologia dan Pendidikan Agama Kristen) 3 (1): 53-65. https://doi.org/10.47166/SOT.V3I1.18. 
BONAFIDE: Jurnal Teologi dan Pendidikan Kristen

www.jurnal.sttissiau.ac.id/Volume 2/Nomor 2/Desember 2021/hal.266-281

Fitriani, Farida Noor. 2014. "Pengaruh Training Islamic Excellent Service Terhadap Kinerja Karyawan Fakultas Syari'ah IAIN Walisongo Semarang." Universitas Islam Negeri Walisongo Semarang.

Gidion, Gidion. 2017. "Profesionalitas Layanan Gereja." Shift Key: Jurnal Teologi dan Pelayanan 7 (2): 89-104. https://doi.org/10.37465/SHIFTKEY.V7I2.12.

Hosea, Amos. 2019. "Fenomena Kelompok Sel (Cell Group) Dalam Gereja Lokal." Diegesis : Jurnal Teologi 4 (1): 1-11. https://doi.org/10.46933/DGS.VOL3I2111.

KKBI. n.d. "Pengaruh ." Kamus Besar Bahasa Indonesia (KKBI). Diakses 23 Desember 2021. https://kbbi.web.id/pengaruh.

Laia, Kejar Hidup. 2019. "Pertumbuhan Gereja dan Penginjilan Di Kepulauan Nias." Fidei: Jurnal Teologi Sistematika dan Praktika 2 (2): 286-302. https://doi.org/10.34081/FIDEI.V2I2.46.

Latif, Helen Farida. 2018. "Pengaruh Pengajaran dan Persekutuan Terhadap Tingkat Pertumbuhan Rohani Anak dan Remaja." EPIGRAPHE: Jurnal Teologi dan Pelayanan Kristiani 1 (2): 119. https://doi.org/10.33991/epigraphe.v1i2.18.

Margareta, Marta. 2020. "Pentingnya Penginjilan Bagi Pertumbuhan Gereja dalam Perintisan Jemaat Baru.” https://doi.org/10.31219/OSF.IO/2EA7C.

Mudak, Sherly. 2017. "Makna Doa Bagi Orang Percaya." Missio Ecclesiae 6 (1): 97 111. https://doi.org/10.52157/ME.V6I1.70.

Padang, Serli Marhayanti, dan Paskalinus Busthan. 2019. "Kajian Kelompok Sel Terhadap Pertumbuhan Rohani Pemuda Di Gereja Kemah Injil Indonesia Mazmur Termindung Samarinda." Repository Skripsi Online 1 (1): 62-67. https://skripsi.sttjaffray.ac.id/index.php/skripsi/article/view/25.

Ritonga, Nova. 2020. "Teologi Sebagai Landasan Bagi Gereja dalam Mengembangkan Pendidikan Agama Kristen.” Jurnal Shanan 4 (1): 21-40. https://doi.org/10.33541/shanan.v4i1.1766.

Siregar, Marigan Pahala. 2021. "Pengaruh Kelompok Sel Terhadap Pertumbuhan Jemaat Gereja Bethel Indonesia Simalingkar B Medan.” HAGGADAH: Jurnal Teologi dan Pendidikan Kristen 2 (1): 42-51. http://sttmwc.ac.id/ejournal/index.php/haggadah.

Soeherman, Sylvia. 2003. "Tujuan Pengajaran Gereja dan Implikasinya." Veritas: Jurnal Teologi dan Pelayanan 4 (1): 107-19. https://doi.org/10.36421/VERITAS.V4I1.101.

Sophia, Selvyen, Fransiskus Irwan Widjaja, dan Alexander Djuang Papay. 2019. "Studi Tentang Tugas Tanggung Jawab Gereja Serta Implikasinya Terhadap 
BONAFIDE: Jurnal Teologi dan Pendidikan Kristen

www.jurnal.sttissiau.ac.id/Volume 2/Nomor 2/Desember 2021/hal.266-281

Pelayanan Misi dan Penginjilan di Kota Batam." REAL DIDACHE: Jurnal Teologi dan Pendidikan Agama Kristen 4 (2).

Susanto, Hery. 2019. “Gereja Yang Berfokus Pada Gerakan Misioner.” Fidei: Jurnal Teologi Sistematika dan Praktika 2 (1): 62-83. https://doi.org/10.34081/FIDEI.V2I1.23.

Sutoyo, Daniel. 2012. "Komunitas Kecil Sebagai Tempat Pembelajaran Gaya Hidup Kristen.” Jurnal Antusias 2 (2): 1-22. https://sttintheos.ac.id/ejournal/index.php/antusias/article/view/31.

Widjaja, Imron. 2019. "Perkembangan Komsel Pelajar Dalam Pertumbuhan Rohani Jemaat GBI Graha Pena Jakarta." The Way Jurnal Teologi dan Kependidikan 5 (2): $\quad 88-100 . \quad$ https://journal.sttbetheltheway.ac.id/index.php/teologi-dankependidikan/article/view/6.

Wijaya, Hengki. 2015. Prinsip-Prinsip Pertumbuhan Gereja Berdasarkan Kitab Kisah Para Rasul. https://doi.org/10.13140/RG.2.1.3113.0324. 